\title{
Synergizing the deltamethrin larvicidal activity against Aedes albopictus larvae using cinnamaldehyde in Diwaniyah, Iraq
}

\author{
M.J. Ali ${ }^{1}$, A.C. Karawan ${ }^{2}$, D.R. Al-Fetly ${ }^{3}$ and M.A. Alfatlawi ${ }^{4}$ \\ 1,2,4 Department of Veterinary Microbiology and Parasitology, ${ }^{3}$ Department of Internal Medicine, College of Veterinary \\ Medicine, University of Al-Qadisiyah, Al-Diwaniyah, Iraq \\ Email: ${ }^{1}$ mansour_para@yahoo.com, ${ }^{2}$ karawan@gmail.com, 3dhafer.hahmeed@qu.edu.iq, ${ }^{4}$ monyerr.abd@qu.edu.iq
}

(Received August 21, 2019; Accepted September 11, 2019; Available online June 13, 2020)

\begin{abstract}
The current work on mosquito larvae was performed to evaluate the resistance status of larvae to deltamethrin (DM) and to detect if the larvicidal activity (LA) of this chemical could be synergized after exposing the larvae to cinnamaldehyde (CD). Here, 200 Aedes albopictus larvae were employed for the experiment and were divided randomly into 2 groups (100/each group and placed in petri-dishes (PD), 10 larvae/PD), and they are the DM group $(1 \mathrm{ml}$ of $0.04 \mathrm{mg} / \mathrm{l}$ in $99 \mathrm{ml}$ of distilled water (DW) was placed to each PD) and the DM+CD group ( $1 \mathrm{ml}$ of $0.04 \mathrm{mg} / \mathrm{l}$ and $1 \mathrm{ml}$ of $0.9 \mathrm{mg} / 1$ respectively were placed with $98 \mathrm{ml} \mathrm{DW}$ in each PD). The experiment was lasted for $24 \mathrm{hrs}$. Larvae were detected to have resistance against DM as $45 \%$ to $60 \%$ of the larvae were killed by the DM, $40 \%$ to $55 \%$ resistance rate. However, when evaluating DM activity with the use of $\mathrm{CD}$, the LA was synergized showing mortality in $87 \%$ to $92 \%$ of the larvae in which a significant increase in the mortality in $\mathrm{DM}+\mathrm{CD}$ group was noticed more than that in the DM group. Furthermore, RT-qPCR was run to identify the expression status of the P540 monooxygenase gene, Cyp6p15, and found that the gene expression was significantly inhibited in the DM+CD group when comparing that in the DM group that showed overexpression of this gene. This work results provide viable information about the potential activity of the cinnamaldehyde in synergizing the larvicidal activity of deltamethrin.
\end{abstract}

Keywords: cinnamaldehyde, deltamethrin, larvicide, resistance

DOI: 10.33899/ijvs.2019.126026.1212, ( ) 2020, College of Veterinary Medicine, University of Mosul.

This is an open access article under the CC BY 4.0 license (http://creativecommons.org/licenses/by/4.0/).

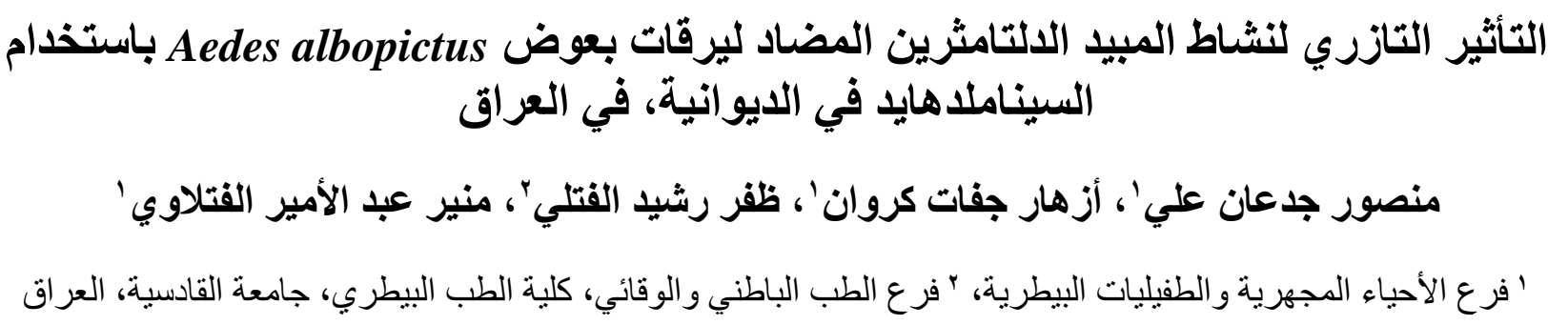

الخلاصة

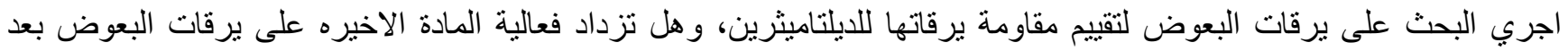

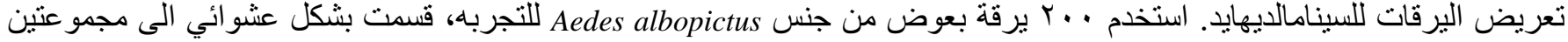

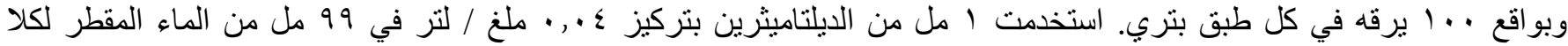

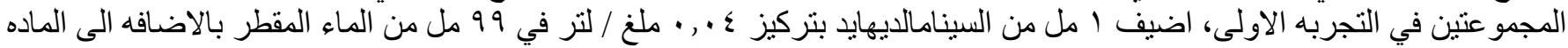

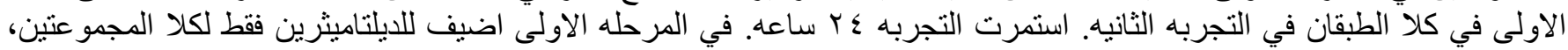

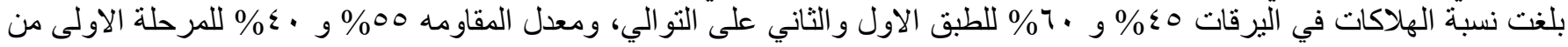

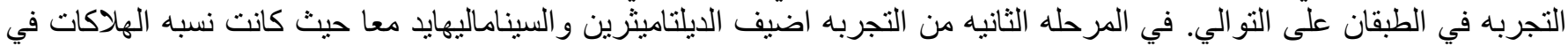

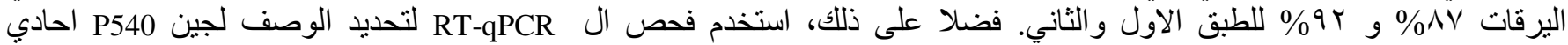


الاوكسجين، Cyp6p15، لوحظ ناثثير جيني كبير عند استخدام الديلتاميثرين و السيناماليهايد معا مقارنه مع التاثير الجيني عند استخدام الديلتاميثرين فقط. ان نتائج هذا البحث اظهرت تالثير تعاضدي للسينامالديهايد مع الديلتاميثرين في استخدام الاخير كمبيد ليرقات البعوض البئ

\section{Introduction}

Resistance to insecticide is an important global subject that affects people life in different health and economic subjects. Mosquitoes are considered as one of the most important disease transmitting vectors (1-3). Mosquitoes are a well-known vector to transmit different pathogens such as plasmodium (4), dengue virus (5), the west Nile virus (6), the yellow fever virus (7), Zika virus (8). Those pathogens cause severe health conditions that sometimes result in high mortalities in human (9). Controlling of these diseases depends highly on controlling those vectors; however, the process has become not easy as insecticide resistance emerges every day to different insecticides, the old or the newly invented insecticides (10). Mosquitoes are being understood to develop insecticide resistance via different mechanisms such as the P450 monooxygenase system present in mosquitoes that acts to generate detoxification of insecticides by P450-dependent degradation processes (11). Interestingly, these detoxification techniques also were suggested via the presence of bacterial P450 of the mosquito microbiota (12-14).

Using insecticide without efficient and successful results introduces more complication into the environment leading to catastrophic pollution that adds more impacts on the health and economy of the world $(15,16)$. The current work on mosquito larvae was performed to evaluate the resistance status of larvae to deltamethrin (DM) and to detect if the larvicidal activity (LA) of this chemical could be synergized after exposing the larvae to cinnamaldehyde (CD).

\section{Materials and methods}

The protocol of larval rearing and conditions was followed from $(14,17,18)$. Here, 200 Aedes albopictus larvae (third instar) were employed for the experiment and were divided randomly into 2 groups (100/each group and placed in petri-dishes (PD), 10 larvae/PD), and they are the DM group ( $1 \mathrm{ml}$ of $0.04 \mathrm{mg} / \mathrm{l}$ in $99 \mathrm{ml}$ of distilled water (DW) was placed to each PD) and the DM+CD group (1ml of $0.04 \mathrm{mg} / \mathrm{l}$ and $1 \mathrm{ml}$ of $0.9 \mathrm{mg} / \mathrm{l}$ respectively were placed with $98 \mathrm{ml} \mathrm{DW}$ in each PD). These PDs were incubated under the conditions of $27 \pm 2^{\circ} \mathrm{C}$ and $85 \%$ of humidity. The experiment was lasted for $24 \mathrm{hrs}$. A triplicate for each group was performed.

\section{RT-qPCR}

For this part of this study, the experiment was re-run to collect the live larvae after 20hrs. The total RNA was extracted using the hot phenol extraction method (19). The gene expression of the P450 monooxygenase, Cyp6p15, was tested. The cDNA was synthetized using 100ng of the RNA and following the use of RevertAid Premium Kit (Fermentas, USA). The RT-qPCR was done using KAPA SYBR FAST qRT-PCR Kit (Biosystem, USA) in the BioRad system (Hercules, USA) using the primers F: CGG ATA TTC AGG AGA GG and R: ATA ACC AGG TCG TAT GT. The normalization gene used was $r p L 8$ (GenBank M99055.1). The conditions and methodology used for the RT-qPCR were from (20).

\section{Statistical analyses}

Mean \pm SE were employed to process and display the data at a significant probability at $\mathrm{P}<0.05$. Graphpad Prism software V7.0 (USA) was recruited to do the analyses.

\section{Results}

\section{Larval mortality}

Larvae were detected to have resistance against DM as $45 \%$ to $60 \%$ of the larvae were killed by the DM, $40 \%$ to $55 \%$ resistance rate. However, when evaluating DM activity with the use of $\mathrm{CD}$, the LA was synergized showing mortality in $87 \%$ to $92 \%$ of the larvae in which a significant increase in the mortality in $\mathrm{DM}+\mathrm{CD}$ group was noticed more than that in the DM group (Table 1) (Figure 1).

Table 1: Shows the mortality rates of the larvae in each group of the experiment

\begin{tabular}{lccc}
\hline \multirow{2}{*}{ Time point } & \multirow{2}{*}{ Triplicates } & \multicolumn{2}{c}{ Mortalities } \\
& 1 & $92(92 \%)$ & $54(54 \%)$ \\
\multirow{3}{*}{ After 24hrs } & 2 & $89(89 \%)$ & $60(60 \%)$ \\
& 3 & $87(87 \%)$ & $45(45 \%)$ \\
\hline
\end{tabular}

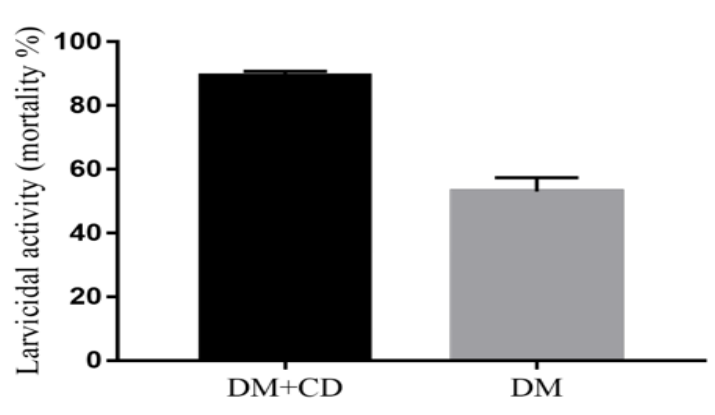

Figure 1: The larvicidal activity comparison between the two experimental groups. 


\section{Cyp6p15 expression}

Cyp6p15 was significantly inhibited in the DM+CD group when comparing that in the DM group that showed overexpression of this gene (Figure 2).

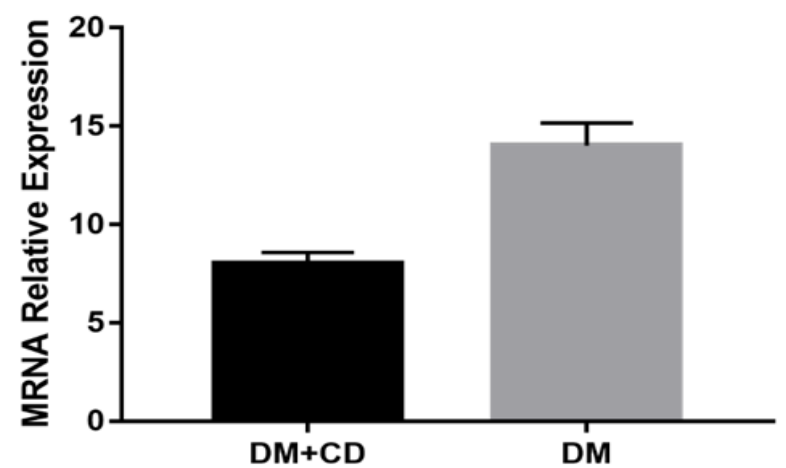

Figure 2: The MRNA relative expression in the two experimental groups.

\section{Discussion}

Resistance to insecticide is an important global subject that affects people life in different health and economic subjects. Mosquitoes are a well-known vector to transmit different pathogens such as plasmodium (4), dengue virus (5), the west Nile virus (6), the yellow fever virus (7), Zika virus (8). Controlling of these diseases depends highly on controlling those vectors; however, the process has become not easy as insecticide resistance emerges every day to different insecticides, the old or the newly invented insecticides (10). Mosquitoes are being understood to develop insecticide resistance via different mechanisms such as the P450 monooxygenase system present in mosquitoes that acts to generate detoxification of insecticides by P450-dependent degradation processes (11). According to this information, the current work was important to be performed to place more successful procedures to control mosquitoes.

The results, here, presented interesting data that Aedes albopictus larvae had resistance against deltamethrin. According to Li et al. (18) who found resistance in larvae of Aedes albopictus against deltamethrin in China, the current results completely agree with that work. The latest workers suggested that this resistance was initiated due to activities of certain enzymes such as P450 monooxygenase especially in adult mosquitoes (18). Difficulty in controlling larval mosquitos or developing resistance against pyrethroid by larvae belong to this mosquito species could end up with spreading and emerging of different diseases that this mosquito transmits such as Dengue and Chikunguny (21). Aedes albopictus, Asian tiger mosquito, is a mosquito species that actively feed on blood by biting during day time $(22,23)$ and was also found to transmit viruses such as
Zika virus (24). Controlling this mosquito via inventing different procedures to overcome the problem of insecticide resistance is important to stop spreading of these pathogens via this mosquito.

Interestingly, the current work results identified that cinnamaldehyde improved the activity of deltamethrin against the larvae employed for this work. Cinnamomum osmophloeum leaf essential oil was found to act as a larvicide against Anopheles gambiae s.s larvae $(17,25)$, and these co-workers predicted that this activity might have been due to cinnamaldehyde (26). The current work used cinnamaldehyde with deltamethrin to synergize the activity of each other resulting in high rates of mortalities in these larvae. This work results provide viable information about the potential activity of the cinnamaldehyde in synergizing the larvicidal activity of deltamethrin.

\section{Conclusion}

To evaluate the resistance status of larvae of mosquito to deltamethrin. We use cinnamaldehyde to study there larvicidal activity of deltamethrin against larvae of mosquito (Aedes albopictus). Larvicidal activity was of deltamethrin synergized and showing mortality reach to $92 \%$ when use cinnamaldehyde.

\section{Acknowledgments}

The authors thank Professor Jabbar Ahmed Alssady Dean of College of Veterinary Medicine, University of AlQadisiyah, Iraq, for technical assistance.

\section{Conflict of interests}

The authors have not received any funding or benefits from industry, agency of financing, or elsewhere to conduct this study.

\section{References}

1. Tolle MA. Mosquito-borne diseases. Curr Probl Pediatr Adolesc Health Care. 2009;39(4):97-140. Doi: 10.1155/2018/6170502

2. Reiter P. Climate change and mosquito-borne disease. Environ Health Perspect. 2001;109(1):141-61. Doi: 10.1289/ehp.01109s1141.

3. Shafie A, Roslan MA, Ngui R, Lim YA, Sulaiman WY. Mosquito biology and mosquito-borne disease awareness among island communities in Malaysia. J Am Mosquito Con Asso. 2016;32(4):27381. Doi: $10.2987 / 8756-971 X-32.4 .351$

4. Aly AS, Vaughan AM, Kappe SH. Malaria parasite development in the mosquito and infection of the mammalian host. Ann Rev Microbiol. 2009;63(1):195-221. Doi: 10.1146/annurev.micro.091208.073403

5. Gubler DJ. Dengue and dengue hemorrhagic fever. Clin Microbiol Rev. 1998;11(3):480-96. Doi: 10.1016/B978-0-7020-3935-5.00075-6

6. Colpitts TM, Conway MJ, Montgomery RR, Fikrig E. West nile virus: biology, transmission, and human infection. Clin Microbiol Rev. 2012;25(4):635-48. Doi: 10.1128/CMR.00045-12 
7. Mutebi JP, Gianella A, Travassos da Rosa A, Tesh RB, Barrett AD, Higgs S. Yellow fever virus infectivity for Bolivian Aedes aegypti mosquitoes. J Emerg Infect Dis. 2004;10(9):1657-60. Doi: 10.3201/eid1009.031124

8. Sultan N, Bukhari SA, Ali I, Asif M, Umar Z, Akash MS. Zika Virus: A critical analysis and pharmaceutical perspectives. Crit Rev Eukaryot Gene Expr. 2018;28(4):7-71. Doi: 10.1615/CritRevEukaryotGeneExpr.2018025061

9. Gubler DJ. Resurgent vector-borne diseases as a global health Problem. Emerg Infect Dis. 1998;4(3):442-450. Doi: 10.3201/eid0403.980326.

10. Hoi AG, Roitberg BD. Mosquito behavior and disease control. Evol Med Public Health. 2014;14(1):162. Doi: 10.1093/emph/eou030

11. Chandor PA, Bibby J, Régent KM, Roux J, Guittard CE, Poupardin R. The central role of mosquito cytochrome P450 CYP6Zs in insecticide detoxification revealed by functional expression and structural modelling. Biochem J. 2013;455(1):75-85. Doi: 10.1042/BJ20130577

12. de Almeida LG, de Moraes LA, de Trigo JR, Omoto C, Cônsoli FL. The gut microbiota of insecticide-resistant insects houses insecticidedegrading bacteria: A potential source for biotechnological exploitation. Plos One. 2017;12(3):1-19. Doi: 10.1371/journal.pone.0174754

13. Ito M, Sato I, Ishizaka M, Yoshida S, Koitabashi M, Yoshida S. Bacterial cytochrome P450 system catabolizing the Fusarium toxin deoxynivalenol. J Appl Environ Microbiol. 2013;79(5):1619-28. Doi: 10.1128/AEM.03227-12

14. Janabi AH. Activation of bacterial cytochrome P450 in the intestine of larval mosquitoes an indication of its role in the insecticide resistance. Basrah J Vet Res. 2017;16(2):85-91. Doi: 10.33762/bvetr.2017.143535

15. Aktar MW, Sengupta D, Chowdhury A. Impact of pesticides use in agriculture: Their benefits and hazards. Interdiscip Toxicol. 2009;2(1):1-12. Doi: 10.2478/v10102-009-0001-7

16. Nicolopoulou SP, Maipas S, Kotampasi C, Stamatis P, Hens L. Chemical pesticides and human health: The urgent need for a new concept in agriculture. Public Health Front. 2016;4(2):148. Doi: $\underline{10.3389 / \text { fpubh.2016.00148 }}$
17. Mdoe PF, Cheng SS, Msangi S, Nkwengulila G, Chang ST, Kweka EJ. Activity of Cinnamomum osmophloeum leaf essential oil against Anopheles gambiae s.s. Parasit Vect. 2014;7(7):209. Doi: 10.1186/1756-3305-7-209

18. Li Y, Xu J, Zhong D, Zhang H, Yang W, Zhou G. Evidence for multiple- insecticide resistance in urban Aedes albopictus populations in southern China. Parasit Vect. 2018;11(4):2-10. Doi: 10.1186/s13071-017-2581-y

19. Jowett T. RNA extraction. New York: Academic Press; 1986. 279-280 $\mathrm{p}$.

20. Chan HH, Wajidi MF, Zairi J. Molecular cloning and xenobiotic induction of seven novel cytochrome P450 monooxygenases in Aedes albopictus. J Insect Sci. 2014;14(1):163. Doi: 10.1093/jisesa/ieu025

21. Bonizzoni M, Gasperi G, Chen X, James AA. The invasive mosquito species Aedes albopictus: Current knowledge and future perspectives. Trends Parasitol. 2013;29(9):460-8. Doi: 10.1016/j.pt.2013.07.003

22. Schaffner F, Medlock JM, Bortel Van W. Public health significance of invasive mosquitoes in Europe. Clin Microbiol Infect. 2013;19(8):68592. Doi: $\underline{10.1111 / 1469-0691.12189}$

23. Paupy C, Delatte H, Bagny L, Corbel V, Fontenille D. Aedes albopictus, an arbovirus vector: From the darkness to the light. Microbes Infect. 2009;11(14-15):1177-85. Doi: 10.1016/j.micinf.2009.05.005

24. Rawal G, Yadav S, Kumar R. Zika virus: An overview. J Family Med Prim Care. 2016;5(3):523-7. Doi: 10.4103/2249-4863.197256

25. Mustafa KA, Al-Baggou BKh. Toxicological and neurobehavioral effects of chlorpyrifos and deltamethrin insecticides in mice. Iraqi $\mathrm{J}$ Vet Sci. 2020;34:189-196. Doi: 10.33899/ijvs.2019.125738.1144

26. Abd Al-Zahra SA, Ahmed AJ. Impacts of processing heat treatments on deltamethrin and bifenthrin residues in human breast milk and raw milk from different animals. Iraqi J Vet Sci. 2018;32:27-31. Doi:10.33899/ijvs.2018.153790 